\title{
V ČEM SPOČÍVÁ ŠKODLIVÝ NÁSLEDEK POUHÉHO ZÁSAHU DO INFORMAČNÍHO SOUKROMÍ ČLOVĚKA BEZ TOHO, ABY BYLO ČLOVĚKU ZASAŽENO DO DALŠÍCH JEHO PRÁV? ${ }^{1}$
}

JAN SVOBODA ${ }^{2}$

\author{
Soud: $\quad$ Court of Appeal (Civil Division), Velká Británie \\ Věc: $\quad$ Lloyd vs Google, HQ17M01913, ref. A2/2018/2769 \\ Datum: $\quad$ 2. 10.2019 \\ Dostupnost: $\quad$ www.pdpjournals.com/docs/888010.pdf
}

\section{1. ÚVOD}

Právo na soukromí, právo na soukromý a rodinný život, právo na informační sebeurčení, právo na informační soukromí a právo na ochranu osobních údajů - to všechno jsou pojmy, které spolu úzce souvisí, avšak až na jednu dvojici (jak bude vysvětleno níže), nejsou zaměnitelné. Do všech z nich, stejně jako do každého práva, lze nicméně zasáhnout, a to způsobem, který může zpo̊sobit újmu nositeli těchto práv. Zásahem do jednoho $\mathrm{z}$ výše uvedených práv pak často může dojít i k zásahu do práv dalších, a to nejen těch uvedených $\mathrm{v}$ tomto článku. Je ale zasažení do práva na informační soukromí, které nezpůsobí zásah do jiného z práv, způsobilé vyvolat škodlivý následek? A pokud ano, v čem tento škodlivý následek spočívá?

Vznik tohoto př́spěvku byl podpořen projektem MUNI/A/0989/2019 (Právo a technologie VIII).

2 Mgr. Jan Svoboda je doktorandem na Ústavu práva a technologií Právnické fakulty Masarykovy univerzity v Brně. Vedle toho působí v mezinárodní advokátní kanceláři PricewaterhouseCoopers Legal. Kontaktní email je jan.svoboda@mail.muni.cz. 
Abychom našli odpověd' na výše uvedené otázky, je třeba pokusit alespoň nastínit vztah mezi jednotlivými právy, jejichž výčet je uveden na začátku tohoto textu. I proto, že se všechny rozebírané pojmy vztahují k obecné, relativně abstraktní, oblasti lidského žití, není jejich uchopení snadné a na poli právní vědy nenajdeme jejich jednotné definice či stoprocentní shodu na tom, jak si vůči sobě vzájemně stojí a nakolik se překrývají. K popsání jejich vztahu se tak pokusím přistoupit zejména za užití zdrojů, které sám považuji za přesvědčivé a jejichž závěry jsou logicky slučitelné. Nemám však potřebu, a ani nemohu, tvrdit, že jsou jediné přijímané či snad dokonce jediné správné.

Následně pro nalezení odpovědi analyzuji relevantní části dvou nedávných rozhodnutí (jedná se o prvostupňové a druhostupňové rozhodnutí v téže věci) z právního prostředí Velké Británie. Oba se přitom vztahují k evropské úpravě ochrany a zpracování osobních údajů a jsou tedy vhodnými případy pro tento příspěvek. Dále předložím několik př́ikladi̊, které charakter zásahu do informačního soukromí člověka blíže ilustrují.

\section{INFORMAČNÍ SOUKROMÍ A S NÍM SOUVISEJÍCÍ POJMY}

Soukromí, respektive právo na soukromí, bývá popisováno, v závislosti na přístupu k němu, jak ve své práci „Conceptualizing Privacy“ uvádí D. J. Solove, jako „právo být ponechán sám sobě“, ${ }^{3}$ „omezení př́istupu k sobě samému“, ${ }^{4}$ „utajení“ (respektive možnost utajení), ${ }^{5}$ „kontrola nad osobními informacemi““, 6 ale také za užití dalších výrazů a přirovnání. ${ }^{7} \mathrm{~V}$ rámci zde překládaného výkladu pak bude pracováno hned s prvním pojetím práva na soukromí, jakožto s právem být „ponechán sám sobě“, a to zejména proto, že krom řady autorů vycházejících $\mathrm{z}$ něho ve svých publikacích jej ve své

3 Označení bylo přeloženo z anglického „Right to Be Let Alone“. Viz SOLOVE, D. J. Conceptualizing Privacy [online]. 90 Cal. L. Rev. (2002) s. 1999-1102 [cit. 8. 5. 2020]. Dostupné z: https://papers.ssrn.com/sol3/papers.cfm?abstract_id $=313103$

4 Označení bylo přeloženo z anglického „Limited Access to the Self“. Tamtéž, s. 1102-1105.

5 Označení bylo přeloženo z anglického „Secrecy“. Tamtéž, s. 1105-1109.

6 Označení bylo přeloženo z anglického „Control Over Personal Information“. Tamtéž, s. 11091116.

7 Tamtéž, s. 1116 a násl. 
rozhodovací praxi aproboval i náš Ústavní soud. Přístup k právu na soukromí jakožto $\mathrm{k}$ právu být ponechán sám sobě můžeme poprvé nalézt $\mathrm{v}$ publikaci „Law of Torts“ z roku 1888 autora T. M. Cooley. O dva roky později stejný př́stup $\mathrm{k}$ soukromí rozvinuli i $\mathrm{S}$. Warren a $\mathrm{L}$. Brandeis ve své práci „The Right to Privacy“, jimž zmíněný popis bývá často nesprávně přisuzován jako těm, kdo jej využili coby první. ${ }^{8}$ Ústavní soud pak zmíněný pohled na soukromí odrazil např̀ ve svém nálezu ze dne 22. 3. 2013, Pl. ÚS 24/10. Překlad do českého jazyka, který Ústavní soud zvolil a v české právní vědě se následně rozšiříil, přičemž je používán i v tomto textu, může mít nicméně negativní, nezamýšlené, konotace. Proto lze doporučit jeho výklad provádět vždy ve světle původního anglického sousloví. ${ }^{9}$

S. Warren a L. Brandeis ve své práci „The Right to Privacy“ argumentují, že práva související s ochranou soukromí nejsou práva vznikající na základě smlouvy, ale práva „vưči světu“ tedy práva erga omnes. ${ }^{10}$ Dále uvádějí, že samotný zásah do tohoto soukromí je hodný požadavku odškodnění, nebot sám o sobě působí psychickou újmu. ${ }^{11}$

Právo na soukromí je $\mathrm{v}$ České republice $\mathrm{v}$ rovině ústavního pořádku chráněno čl. 10 Listiny základních práv a svobod. ${ }^{12}$ Již ten nám napoví, že se soukromí skládá mimo jiné ze soukromého a rodinného života (přičemž můžeme říci, že rodinný život je podsložkou života soukromého) ${ }^{13}$ a z informačního sebeurčení. ${ }^{14}$ Informační sebeurčení tak můžeme považovat, stejně jako činí i $\mathrm{E}$. Wagnerová v rámci komentáře $\mathrm{k}$ výše uvedenému př̀dpisu za

8 Srov. POLČÁK, R.; SVANTESSON, D. Information Sovereignty - Data, Privacy, Sovereign Powers and the Rule of Law. Cheltenham: Edward Elgar Publishing, 2017, s. 82.

9 Srozumitelný přehled přístupu k pojmu soukromí nabízí J. MíšEK ve své práci Osobní údaje $v$ čase a prostoru [online]. Brno, 2020, s. 28-35 [cit. 8. 5. 2020]. Disertační práce. Masarykova univerzita, Právnická fakulta. Vedoucí práce Radim Polčák. Dostupné z: https://is.muni.cz/th/wpa9m/

10 WARREN,D., BRANDEIS, L. The Right to Privacy. Harvard Law Review [online]. 1890, roč. IV, č. 5, s. 213 [cit. 8. 5. 2020]. Dostupné z: https://www.cs.cornell.edu/ shmat/ courses/cs5436/warren-brandeis.pdf

11 Tamtéž.

12 Srov. WAGNEROVÁ, E., In: WAGNEROVÁ, E., a kol. Listina základních práv a svobod. Komentár. Praha: Wolters Kluwer, 2011, čl. 10.

13 Viz čl. 10 odst. 2 Listiny základních práv a svobod a dále pak tamtéž.

14 Viz čl. 10 odst. 3 Listiny základních práv a svobod a dále pak tamtéž. 
součást práva na soukromí. Ústavní soud k právu na informační sebeurčení, které lze, zjednodušeně řečeno, chápat jako možnost kontrolovat informace, případně data, o sobě, ${ }^{15}$ uvádí: „Vedle tradičního vymezení soukromí $v$ jeho prostorové dimenzi (ochrana obydlí $v$ širším slova smyslu) a $v$ souvislosti $s$ autonomní existencí a veřejnou mocí nerušenou tvorbou sociálních vztahů ( $v$ manželství, $v$ rodině, ve společnosti) právo na respekt $k$ soukromému životu zahrnuje i garanci sebeurčení ve smyslu zásadního rozhodování jednotlivce o sobě samém. Jinými slovy, právo na soukromí garantuje rovněž právo jednotlivce rozhodnout podle vlastního uvážení, zda, popř. v jakém rozsahu, jakým způsobem a za jakých okolností mají být skutečnosti a informace z jeho osobního soukromí zpř̌stupněny jiným subjektům. “16

Právo na informační sebeurčení je dle mého názoru, byt̉ jsem si vědom i názorů rozdílných, ${ }^{17}$ zaměnitelné s právem na informační soukromí. Obě jsou totiž bezesporu podsložkou soukromí ${ }^{18}$ a obě se bezprostředně vztahují ke kontrole dat či informací o dané osobě, a to dat a informací celého spektra lidského soukromí. ${ }^{19}$

Právo na ochranu osobních údajů je pak možné vnímat jako institut sloužící k ochraně všech výše uvedených práv, respektive jako jejich podsložku, s tím, že za stěžejní cíl práva na ochranu osobních údajů lze, alespoň v rámci českého právního prostředí, s odkazem na bod odůvodnění 4 Nařízení Evropského parlamentu a Rady (EU) 2016/679 ze dne 27. dubna 2016 o ochraně fyzických osob v souvislosti se zpracováním osobních údajů a o volném pohybu těchto údajů a o zrušení směrnice 95/46/ES (dále jen „GDPR“), a hlavně pak na § 1 zákona č. 110/2019 Sb., o zpracování

15 Srov. DONÁT, J., Tomíšek, J. Právo v síti. Praha: C.H. Beck, 2016, s. 24.

16 Nález Ústavního soudu ze dne 22. 3. 2013, Pl. ÚS 24/10.

17 Viz např. MíŠEK, J. Osobní údaje v čase a prostoru [online]. Brno, 2020, s. 36 [cit. 8. 5. 2020]. Disertační práce. Masarykova univerzita, Právnická fakulta. Vedoucí práce Radim Polčák. Dostupné z: https://is.muni.cz/th/wpa9m/ nebo POLČÁK, R. Internet a proměny práva. Praha: Auditorium, 2012, s. 327.

18 Srov. SOLOVE, D. J. Conceptualizing Privacy [online]. 90 Cal. L. Rev. (2002) s. 1106 [cit. 8. 5. 2020]. Dostupné z: https://papers.ssrn.com/sol3/papers.cfm?abstract_id $=313103$

19 Srov. KOOPS, B. et al. A Typology of Privacy [online]. SSRN Scholarly Paper ID 2754043. Rochester, NY: Social Science Research Network 2016, s. 484 [vid. 8. 5. 2020]. Dostupné z: http://papers.ssrn.com/abstract $=2754043$ 
osobních údajů (dále jen „ZZOÚ“) považovat ochranu soukromí. Ustanovení § 1 ZZOÚ přímo říká, že ZZOÚ $\mathrm{k}$ naplnění práva každého na ochranu soukromí upravuje práva a povinnosti při zpracování osobních údajů. Ochrana osobních údajů tak vytváří prostor pro ochranu distributivních práv a výkon svobod spjatých s lidským soukromím.

Nyní, když jsme nastínili základní vztah mezi jednotlivými právy a způsob, jakým s nimi bude $\mathrm{v}$ rámci tohoto textu pracováno, je vhodné přistoupit ke konkrétnímu případu, který nám rovněž pomůže odpovědět na výše uvedené otázky. Jak bylo avizováno, jedná se o prrípad řešený před soudy Velké Británie, konkrétně před londýnským Hight Court of Justice, v rámci rozhodnutí č. HQ17M01913 ze dne 8. 10. 2018 a následně před Court of Appeal (Civil Division), a to v rámci rozhodnutí č. HQ17M01913, ref. A2/2018/2769, ze dne 2. 10. 2019. Tato rozhodnutí jsou populárně nazývána dle jejich stran jako „Lloyd vs Google“.

\section{LLOYD VS GOOGLE - PRVOSTUPŇOVÉ ROZHODNUTÍ}

$\mathrm{V}$ předmětném rozhodnutí soud projednával žalobu, kterou se pan Lloyd za sebe a další účastníky (4,4 mil uživatelů telefonu typu iPhone ${ }^{20} \mathrm{v}$ rámci hromadné žaloby, domáhal odškodnění za újmu. Ta mu měla vzniknut kvůli počínání společnosti Google. ${ }^{21}$ Google je společností se sídlem v Kalifornii, a tak musel britský soud rozhodovat o přípustnosti hromadné žaloby. Mezi podmínky pro určení př́slušnosti soudu $\mathrm{v}$ tomto ohledu patří i skutečnost, zda je $s$ žalobou spojena dostatečná míra pravděpodobnosti na úspěch. Soud tak musí učinit i některé meritorní úvahy. ${ }^{22}$ Závěry zde prezentované mohou být $\mathrm{v}$ rámci dalšího, již skutečně meritorního, řízení dále změněny. Pro náš výklad není relevantní to, jakou roli v daném sporu hrála problematika hromadných žalob a klasifikace daného sporu pod patřičné řízení. Hromadné žaloby jsou české právní kultuře vzdálené a přes občasné tendence $\mathrm{k}$ jejich zavedení je účinná právní úprava dosud nepřipouští.

\footnotetext{
20 Viz bod 4 daného rozhodnutí.

21 Viz bod 1-3 daného rozhodnutí.

${ }^{22}$ Viz bod 45-53 daného rozhodnutí.
} 
Společnost Google zpracovávala informace generované prohlížečem včetně IP adresy daného zařízení a adresy navštívené stránky, a to za užití souboru cookie (tzv. DoubleClick cookie). Konečným cílem této aktivity bylo zobrazování personalizované reklamy. Uložení souboru cookie a na to navazující zpracovatelské aktivity byly činěny bez souhlasu a bez vědomí uživatele, tedy subjektu údajů (tzv. Safari Workaround) ${ }^{23}$

IP adresa je obecně považována za osobní údaj, ${ }^{24}$ stejně tak lze za osobní údaj považovat velkou část souborů cookie nebo údajů na základě nich předávaných, vč. historie stránek. O trendu podřazování širokého spektra údajů pod pojem osobní údaje ve smyslu účinných právních předpisů pak svědčí např. i rozsudek Krajského soudu v Brně ze dne 7. 11. 2018, č j. 31 A 68/2018-177.

Výše nastíněným postupem společnosti Google v období několika měsíců v letech 2011-2012 došlo k porušení povinností § 4 odst. 4 britského Data Protection Act z roku 1998 (dále jen „DPA“), který v dotčeném období představoval transpozici směrnice 95/46/ES. Dle $\S 13$ odst. 1 DPA má fyzická osoba, která utrpěla újmu $\mathrm{v}$ důsledku porušení jakékoli povinnosti správce uložené DPA, nárok na odškodnění ze strany správce za tuto újmu. Újma zde má dle žalobce spočívat zejména ve ztrátě kontroly nad osobními údaji. ${ }^{25}$ Alternativně žaloba požadovala odškodnění v hodnotě, kterou díky nim Google získal.

Soud však v tomto rozsudku neshledal prosté porušení práva na informační sebeurčení, jak je vymezeno výše v tomto textu, ${ }^{26}$ jako způsobilé pro vznik újmy, nebot daná událost se neprojevila zásahem do práva na soukromí daného jedince. ${ }^{27}$ Soud mimo jiné uvedl, že nesouhlasí s názorem, že osoba, jejíž údaje byly použity v rozporu se zákonem automaticky utrpí odškodnitelnou újmu, zejména škodu nebo psychickou újmu, na základě

\footnotetext{
23 Viz bod 4-8 daného rozhodnutí.

24 Srov. bod odůvodnění 30 GDPR.

25 Srov. bod 58 a 59 daného rozhodnutí.

26 Viz bod 54 daného rozhodnutí.

27 Srov. bod 56 daného rozhodnutí.
} 
spáchání daného přestupku nebo na základě narušení autonomie, která se k nakládání s osobními údaji vztahuje. ${ }^{28}$

V daném rozhodnutí pak ze strany soudu byla použita řada argumentů pro podložení výše uvedeného závěru. Jedním z nich bylo tvrzení, že někteří lidé mají radost $\mathrm{z}$ večírku uspořádaného jakožto překvapení. Dalším pak existence řady dlouhotrvajících vztahů vzniklých díky tomu, že společný prítel dvou osob předal kontakt jedné osoby té druhé bez jejího souhlasu. Na tomto místě je však třeba upozornit, že nelze bez dalšího srovnávat užití osobních údajů pro ryze osobní účely a užití osobních údajů pro zbylé aktivity, zejména pak ty komerční. ${ }^{29}$ Dané argumenty tak nelze považovat za relevantní pro tento případ. Nadto je třeba uvést, že spíše než že při výše uvedených případech nevzniká újma (škodlivý následek), nevzniká újma takové intenzity, aby nebyla převážena jinými faktory, $\mathrm{v}$ jejichž důsledku na újmu subjekty údajů vlastně zapomenou, čili jim je nezřídka zároveň kompenzována jiným aspektem daného činu.

Výše uvedené závěry pak nepřevzal odvolací soud. Rozdílné posouzení prvostupňovým a druhostupňovým soudem pochopitelně není zvláštností. Svědčí to nicméně o problematičnosti př́ípadu a omezené možnosti představit si všechny vztahy a významy relativně abstraktních pojmů uvedených $\mathrm{v}$ úvodu tohoto textu, $\mathrm{k}$ nimž se více či méně explicitně daná rozhodnutí váží.

\section{LLOYD VS GOOGLE - DRUHOSTUPŇOVÉ ROZHODNUTÍ}

Odvolací soud otázku, zda je možné poskytnout odškodnění pro samotnou ztrátu kontroly nad daty, aniž by byla způsobena škoda nebo psychická újma, zhodnotil jinak. ${ }^{30}$ Vyšel mimo jiné $\mathrm{z}$ faktu, že $\S 13$ DPA představuje transpozici směrnice, která byla přijata pro výkon čl. 8 Charty základních práv EU. ${ }^{31}$ Předně popsal, že samotná kontrola nad daty představuje určitou hodnotu. Odůvodnil to např́klad tím, že mohou být prodána (nikoli ve

\footnotetext{
28 Viz bod 74 daného rozhodnutí.

${ }^{29}$ Srov. např. čl. 2 GDPR.

30 Bod 70 daného rozhodnutí.

31 Srov. bod 42 daného rozhodnutí.
} 
smyslu převedení vlastnictví, nýbrž ve smyslu umožnění jejich zpracování). Většinou je možnost zpracovávat data směňována přímo za určitou službu (nikoli tedy za peníze), např. za přístup $\mathrm{k}$ wifi či za umožnění využívání určitého programu. ${ }^{32}$

Ve světle výše uvedeného pak odvolací soud rozhodl, že samotná ztráta kontroly nad osobními údaji způsobená porušením správcovy povinnosti dle DPA je způsobilá založit nárok k odškodnění, a to bez nutnosti dalšího dokazování. Dané rozhodnutí tak výrazně posiluje pozici subjektů údajů a ochranu jejich osobních údajů bez ohledu na to, jaké konsekvence porušení správcových povinností na ochranu osobních údajů vyvolalo.

\section{CHARAKTER ZÁSAHU DO INFORMAČNÍHO SOUKROMÍ}

Ptáme-li se, v čem spočívá škodlivý následek porušení ztráty osobních údajů, je to, jak ukazuje i druhostupňové rozhodnutí Lloyd vs Google, právě ona ztráta kontroly nad těmito daty.

Ztráta kontroly nad vlastními daty nemusí nutně vést například ke zneužití identity, odhalení choulostivých informací pro udržení dobré pověsti, zveřejnění informací zneužitelných $\mathrm{v}$ rámci diskriminačních praktik či jiných znatelných zásahů do soukromí. Vždy ale vede k zásahu do svobody vůle. Disponuje-li někdo našimi osobními údaji bez řádného právního důvodu, znemožňuje nám tím nejen možnost mu tyto údaje v budoucnu poskytnout, ale například i možnost s ním souhlas se zpracováním svých údajů za něco směnit. ${ }^{33}$ Odpověd" na otázku, zda je zasažením do práva na informační soukromí, které nezpůsobí zásah do jiného z práv, způsobilé vyvolat škodlivý následek, je tedy ano.

Omezení svobody vůle pak spočívá i v tom, že své osobní údaje můžeme mít zájem poskytnout pouze takovému správci, kterému důvěřujeme, a to zejména pro jeho reputaci v oblasti zabezpečení těchto údajü. ${ }^{34}$ Ve vztahu k zabezpečení pak mohu mít zájem vykonávat určité kontrolní kroky. Ne-

32 Body 46-47 daného rozhodnutí.

33 Srov. body 46-47 druhostupňového rozhodnutí Lloyd vs Google.

34 Srov. kapitola IV oddíl 2 GDPR nebo ÚOOÚ. Zabezpečení osobních údajů [online]. Vytvořeno / změněno: 27. 10. 2017 / 25. 4. 2019 [cit. 8. 5. 2020]. https://www.uoou.cz/8-zabezpeceni-osobnich-udaju/d-27282/p1 = 3938 
vím-li však, že někdo zpracovává mé osobní údaje, nemohu tuto kontrolu logicky ani vykonávat.

V neposlední řadě pak svoboda vůle bezpochyby zahrnuje i svobodu někoho nepodpořit $\mathrm{v}$ jeho činnosti, a to i neposkytnutím svých osobních údajů. Byt jsme nic $\mathrm{z}$ výše uvedeného nemuseli mít zájem učinit, neopravňuje toto nikoho nám danou možnost upřít.

Z výše uvedeného je tak patrné, že zásah do informačního soukromí nemusí nutně představovat zásah do soukromého života či do soukromí, vždy ale představuje zásah alespoň do svobody vůle, byt třeba aktuálně nevykonávané/neprezentované. Toto se pokusím uvést na dvou dalších př́kladech. První př́klad můžeme znát spíše ze cvičení argumentace v oblasti morálních otázek. I když se většinou nepoužívá pro vysvětlování aspektů informačního soukromí, věřím, že se v této oblasti osvědčí. Jedná se o situaci osoby, která se ráda opaluje nepozorována nahá. Činí tak na svém oploceném pozemku, kam za standardních okolností není vidět. Jednoho dne ale na nedalekou lampu vyleze jiná osoba a záměrně ji pozoruje. Nefotí ji a její fotografie tedy logicky ani nijak nemonetizuje. $\mathrm{V}$ tomto ohledu jí tak nepřipravuje o zisk. O její zálibě nikomu neříká. Neposkytuje tedy nikomu možnost $\mathrm{k}$ užití těchto informací $\mathrm{v}$ rámci diskriminace nebo snad, připadalo-li by daného chování někomu z jakéhokoli důvody třeba nemravné, $\mathrm{k}$ poškození pověsti. $\mathrm{O}$ zneužití identity pak z podstaty věci nemůže být řeč.

Zasahuje však do její svobody vůle. Její první preferencí je totiž opalovat se nahá a nepozorovaná. Druhou pak s největší pravděpodobností není opalovat se nahá a pozorovaná, nýbrž neopalovat se vůbec nebo se opalovat v plavkách.

Odhlédněme ted" od toho, že pozorující osoba by jen stěží hledala legitimní důvod pro zásah do informačního soukromí třeba „jen“ z morálního hlediska a zaměřme se na to, že opalující se osobu neupozornila na fakt, že je sledována. Kdyby na ni totiž z lampy zapískala, minimálně by se opalující se osoba oblékla a tím mimo jiné (vlastně znovu) vyjádřila svou vůli komu se (ne)chce při opalování odhalovat.

Aniž by tedy pozorující osoba způsobila efekt zjevně viditelný v soukromí jiného člověka, připravila opalující se osobu o možnost volní reakce 
na danou situaci. Dále ji nechala v omylu jejího legitimního očekávání, že má danou situaci fakticky pod kontrolou. Obdobná možnost byla odepřena i uživatelům iPhonu v případě Lloyd vs Google. Je totiž možné předvídat, že by někteří $\mathrm{z}$ nich, obdobně $\mathrm{k}$ aktu obléknutí, přistoupili $\mathrm{k}$ používání jiného telefonu, jiného prohlížeče či k jinému chování na internetu.

Druhý př́iklad je svým charakterem o něco podobnější tomu z př́ípadu Lloyd vs Google. Představme si osobní spis bývalého zaměstnance, pro jehož uchování již neexistuje právní základ. Bývalý zaměstnavatel by tedy měl spis skartovat. Neučiní tak, ale zavře ho do trezoru a kromě samotného uložení údaje v něm obsažené nijak nezpracovává. Uchovává ho nicméně $\mathrm{v}$ rozporu s právem. $\mathrm{V}$ daném případě zaměstnanec nepřichází o možnost směny svých osobních údajů, nebở zaměstnavatel tyto, vzhledem ke způsobu jejich zpracování, zjevně nepotřebuje. Uložení v trezoru pak nepředstavuje přímé ohrožení ve smyslu možnosti zneužití jeho identity či dalšího zveřejnění jeho osobních údajů. Opět ale dochází ke ztrátě kontroly. Neví-li zaměstnanec o určitém zpracování, nemůže provádět ani výše uvedenou úvahu ve vztahu k zabezpečení a logicky pak ani vykonávat svá práva jakožto práva subjektu údajů. Volní rozhodnutí o tom, jakým způsobem s jeho osobními údaji bude nakládáno, pak bez ohledu na zaměstnancovo další jednání chybí a je tedy opět zasahováno do jeho svobody vůle.

Rozlišujeme-li striktně mezi právy a svobodami, můžeme uzavřít, že zásahem do informačního soukromí, který nepředstavuje zásah do dalších práv, je vždy omezena svoboda vůle. $\mathrm{V}$ tom lze tedy spatřovat onen škodlivý následek.

Nadto-lze další škodlivý následek spatřovat $\mathrm{v}$ zásahu do systému práva na ochranu osobních údajů, př́padně do systému práva na informační soukromí. Tyto systémy jsou totiž chráněny řadou komplexních pravidel, přičemž při jejich porušování se přesouváme od zvýšení informovanosti tohoto systému $\mathrm{k}$ prvkům nežádoucí entropie a daný systém tak z informačního pohledu strádá. Pracujeme-li s př́stupem, že tento systém slouží jako prostředek k ochraně dalších distributivních práv a svobod, tak přesto, že daný zásah do něj nemusí nutně znamenat zásah do dalšího konkrétního 
práva, snižuje kvalitu ochranného prostředí jako celku, což může vyústit v intenzivnější škodlivý následek v budoucnosti.

\section{ZÁVĚR}

V textu byl nejdříve podán výklad pojmu práva na soukromí a s ním souvisejících institutů, včetně popisu jejich vztahu. Uvedeny byly přístupy $\mathrm{k}$ pojmu soukromí s důrazem na jeho pojetí formulovaném $\mathrm{S}$. Warrenem a L. Brandeisem.

Pro zodpovězení otázek, zda je zasažení do práva na informační soukromí, které nezpůsobí zásah do jiného z práv, zpơsobilé vyvolat škodlivý následek a v čem tento škodlivý následek spočívá, bylo rozebráno prvostupňové i druhostupňové rozhodnutí Lloyd vs Google. Na takto podaném výkladu bylo ukázáno, že takový škodlivý následek možné vyvolat je a že tento spočívá zejména v omezení svobody vůle. Pro tento závěr je stěžejní důsledně rozlišovat mezi právy a svobodami.

Nad to byl škodlivý efekt identifikován ve snížení organizovanosti systému ochrany informačního soukromí, který má obecně za cíl chránit další distributivní práva. Toto pak může způsobit dodatečné škodlivé efekty $\mathrm{v}$ budoucnu.

Závěrem je myslím vhodné připomenout hysterii okolo blížící se použitelnosti GDPR v roce 2018. Ta mohla řadu subjektů údajů nepochybně utvrdit $\mathrm{v}$ důležitosti těchto údajů takovým způsobem, že je zcela legitimní očekávat, že jim prostý zásah do informačního soukromí způsobí psychickou újmu, byṫ třeba nepodloženou zásahem do dalších práv.

\section{ZDROJE:}

\subsection{ODBORNÁ LITERATURA:}

[1] DONÁT, J., Tomíšek, J. Právo v síti. Praha: C.H. Beck, 2016, 352 s., ISBN 978-80-7400610-4.

[2] KOOPS, B. et al. A Typology of Privacy [online]. SSRN Scholarly Paper ID 2754043. Rochester, NY: Social Science Research Network 2016, 93 s. [vid. 8. 5. 2020]. Dostupné z: http://papers.ssrn.com/abstract $=2754043$ 
[3] MÍŠEK, J. Osobní údaje v čase a prostoru [online]. Brno, 2020, 231 s. [cit. 8. 5. 2020]. Disertační práce. Masarykova univerzita, Právnická fakulta. Vedoucí práce Radim Polčák. Dostupné z: https://is.muni.cz/th/wpa9m/

[4] POLČÁK, R. Internet a proměny práva. Praha: Auditorium, 2012, 392 s., ISBN 978-8087284-22-3.

[5] POLČÁK, R.; SVANTESSON, D. Information Sovereignty - Data, Privacy, Sovereign Powers and the Rule of Law. Chltenham: Edward Elar Publishing, 2017, 262 s., ISBN 978-1-78643-921-5.

[6] SOLOVE, D. J. Conceptualizing Privacy [online]. 90 Cal. L. Rev. (2002) 70 s. [cit. 8. 5. 2020]. Dostupné z: https://papers.ssrn.com/sol3/papers.cfm?abstract_id = 313103

[7] ÚOOÚ. Zabezpečení osobních údajů [online]. Vytvořeno / změněno: 27. 10. 2017 / 25. 4. 2019 [cit. 8. 5. 2020]. https://www.uoou.cz/8-zabezpeceni-osobnich-udaju/d-27282/ p1 $=3938$

[8] WAGNEROVÁ, E., a kol. Listina základních práv a svobod. Komentářr. Praha: Wolters Kluwer, 2011, 931 s., ISBN 978-80-7357-750-6.

[9] WARREN, D., BRANDEIS, L. The Right to Privacy. Harvard Law Review [online]. 1890, roč. IV, č. 5, 29 s. [cit. 8. 5. 2020]. Dostupné z: https://www.cs.cornell.edu/ shmat/courses/ cs5436/warren-brandeis.pdf

\subsection{PRÁVNÍ PŘEDPISY:}

[10] Britský Data Protection Act z roku 1998

[11] Listina základních práv a svobod

[12] Nařízení Evropského parlamentu a Rady (EU) 2016/679 ze dne 27. dubna 2016 o ochraně fyzických osob v souvislosti se zpracováním osobních údajů a o volném pohybu těchto údajů a o zrušení směrnice 95/46/ES (obecné nařízení o ochraně osobních údajů)

[13] Směrnice Evropského parlamentu a Rady 95/46/ES ze dne 24. října 1995 o ochraně fyzických osob v souvislosti se zpracováním osobních údajů a o volném pohybu těchto údajů

[14] Zákon č. 110/2019, o zpracování osobních údajů

\subsection{SOUDNÍ ROZHODNUTÍ:}

[15] Rozhodnutí Royal Courts of Justice, Court of Appeal, HQ17M01913, ref. A2/2018/2769, ze dne 2. 10. 2019

[16] Nález Ústavního soudu ze dne 22. 3. 2013, Pl. ÚS 24/10

[17] Rozsudek Krajského soudu v Brně ze dne 7. 11. 2018, č.j. 31 A 68/2018-177

Toto dílo lze užít v souladu s licenčními podmínkami Creative Commons BY-SA 4.0 International (http://creativecommons.org/licenses/by-sa/4.0/legalcode). 